Caries Res. 1982;16:I-VI

\title{
Contents, Vol. 16, 1982
}

\section{No. 1 Original Paper}

Radiographic Diagnosis and Clinical Tissue Changes in Relation to Treatment of Approximal Carious Lesions

Bille, J.; Thylstrup, A 1

Fluoride Content in Enamel after Repeated Applications of Fluoride Varnishes in a Com munity with Fluoridated Water

Seppä, L.; Luoma, H.; Hausen, H 7

Preliminary Studies on Calcium Lactate as an Anticaries Food Additive

Shrestha, B.M.; Mundorff, S.A.; Bibby, B.G 12

In vivo Relationships of the Dextran-Degrading Oral Microbiota to Streptococcus mutans and Caries Experience

Staat, R.H.; Langley, S.D.; Swenson, J.I 18

Artificial Lesion Formation and Fluoride Uptake after T1F4 Applications

Wefel, J.S 26

Effect on Fluoride Uptake by Enamel and on the Progress of Artificially Produced Caries-

Like Lesions of Applying Successively Two Different Fluoride Solutions

Joyston-Bechal, S.; Kidd, E.A.M 34

Relationship between the Extent of the Initial Lesion and the Inhibitory Effect of APF on the Progression of Caries-Like Lesions in vitro

Kidd, E.A.M.; Joyston-Bechal, S 42

Microcrystal Arrangement in Human Deciduous Dental Enamel Studied by Electron Para magnetic Resonance

Skaleric, U.; Ravnik, C; Cevc, P.; Schara, M 47

Surface Characteristics of Hydroxyapatite and Enamel after Adsorption of Fluoride-Con taining Macromokcuks

Bartels, T.; Pelt, A.W.J. van; Jong, H.P. de; Arends, J 51

Fluoridation of Human Enamel by Fluoride-Containing Polyekctrolytes

Bartels, T.; Kelders, H.; Arends, J 57

Changing Pattterns of Enamel Matrix Proteins in the Developing Bovine Tooth

Fincham, A.G.; Belcourt, A.B.; Termine, J.D 64

Ethyknediaminetetraacetic Acid Insoluble Protein of Adult Human Enamel

Belcourt, A.B.; Fincham, A.G.; Termine, J.D 72

Short Communication

Effect of Topical Fluoride Gel Applications on Caries Incidence in Rats

Hefti, A

77

Announcements

80

No. 2 Original Paper

Structure of Extracellular Glucans Synthesized by Streptococcus mutans of Serotypes a-e in vitro 
Trautner, K.; Birkhed, D.; Svensson, S 81

Maltitol and Maltotriitol as Inhibitors of Acid Production in Human Dental Plaque

Würsch, P.; Koellreutter, B 90

Contents

III

A Biochemical Micromethod to Characterize Streptococcus mutans

Oldershaw, M.D.; Eisenberg, A.D.; Curzon, M.EJ 96

Prediction of Mean Caries Experience of Samples of the Australian Population

Spencer, A.J.; Eklund, S.A 103

Effect of Topical Application of Urea Peroxide on Caries Incidence and Plaque Accumula tion in Rats

Firestone, A.R.; Schmid, R.; Mühlemann, H.R 112

Demineralization of Human Dental Enamel by Karaya Gum Solutions

Lamb, D.J.; Craig, G.T 118

The Effect of Flow Rate on the Ionized Calcium Concentration of Human Parotid Saliva

Lagerlöf, F.; Ekstrand, J 123

Thickness of Enamel Layers Removed by HCIO4 Etching

Dijkman. A.G.; Arends, J 129

Fluoride Accumulation by Streptococcus mutans from a Low Ionic Medium

Mante, S.; Yotis, W.W 138

Fluoride Deposited by Topical Applications in Enamel. KOH-Soluble and Acquired Fluo ride

Dijkman, A.G.; Tak, J.; Arends, J 147

Fluoride Taken Up by Plaque, by the Underlying Enamel and by Clean Enamel from Three Fluoride Compounds in vitro

Klimek, J.; Hellwig, E,; Ahrens, G 156

Fluoride Uptake and in vitro Caries-Like Lesion Formation in Enamel after Two-Step Top ical Fluoride Applications

Crall, J.J.; Silverstone, L.M.; Clarkson, B.H.; Wefel, J.S.; Wei, S.H.Y 162

Chemical and Morphological Aspects of Fluoride Acquisition by Enamel from Topical

Application of Ammonium Fluoride with Ammonium Monofluorophosphate

Caslavska, V.; Gron, P.; Stern, D.; Skobe, Z 170

Ultrastructure of Striations in Carious Human Enamel

Simmelink, J.W.; Nygaard, V.K 179

Short Communications

The Influence of Manganese on Carbohydrate Metabolism and Caries Induction by Strepto coccus mutans Strain Ingbritt

Beighton, D 189

Demineralisation of Human Enamel by Streptococcus mutans NCTC 10832 Using a Sequen

tial Batch Culture Technique

Dummer, P.M.H.; Edmunds, D.H.; Green, R.M 193

Comparison of Fluoride Uptake by Human Enamel from Acidulated Phosphate Fluoride

Gels with Different Fluoride Concentrations

Dijkman, A.G.; Tak, J.; Arends, J 197

No. 3 Basic Sciences

Alternating Demineralization and Remineralization of Artificial Enamel Lesions 
Cate, J.M., ten; Duijsters, P.P.E 201

Phosphate Diffusion in Whole Bovine Enamel. III. pH Dependency

Rooij, J.F., de; Arends, J -11

Preparation of Partially Decalcified Sections of Human Dental Enamel for

Electron Microscopy

Liem, R.S.B.; Jansen, H.W.B 217

IV

Contents

Animal Studies

Macroscopic Appearance, Microhardness and Microradiographic Characteristics of Experi mentally Produced Fluorotic Lesions in Sheep Enamel

Suckling, G.W.; Purdell-Lewis, D 227

Clinical Science

Remineralization of Artificial Caries-Like Lesions in vivo by a Self-Administered Mouthrinse or Paste

Featherstone, J.D.B.; Cutress, T.W.; Rodgers, B.E.; Dennison, P.J 235

A Preliminary Study of Posteruptive Maturation of Teeth in situ

Brudevold, F.; Aasenden, R.; Bakhos, Y 243

Bioavailability of Fluoride Added to Baby Formula and Milk

Spak, C.J.; Ekstrand, J.; Zylberstein, D 249

Comparison of Dental Health of 11-Year-Old Children in 1970 and 1979, and of 14-Year-

Old Children in 1973 and 1979: Studies in Bristol, England

Andlaw, R.J.; Burchell, C.K.; Tucker, G.J 257

Prevalence and Intraoral Distribution of Root Caries in an Adult Population

Katz, R.V.; Hazen, S.P.; Chilton, N.W.; Mumma, R.D., Jr 265

Reduction in Caries after 7 Years of Water Fluoridation under Climatic Conditions in

Cuba

Künzel, W 272

No. 4 Basic Sciences

Caries Preventive Doses of Fluoride and Cyclic AMP Levels in Human Plasma

Mörnstad, H.; Dijken, J. van 277

The Effect of Fluoride on the Uptake of Albumin by Hydroxyapatite

Eggen, K.H.; Rölla, G282

Influence of Sodium Chloride on Fluoride Reactions with Dental Tissues

Ericsson, Y 287

The Effect of Fluoride and Stannous Ions on Streptococcus mutans. Viability, Growth, Acid,

Glucan Production, and Adherence

Ferretti, G.A.; Tanzer, J.M.; Tinanoff, N 298

Crystallinity Changes of C03-Apatites in Solutions at Physiological $\mathrm{pH}$

Okazaki, M.; Moriwaki, Y.; Aoba, T.; Doi, Y.; Takahashi, J.; Kimura, H 308

Limiting Factors for the Generation of Hypothiocyanite Ion, an Antimicrobial Agent, in

Human Saliva

Pruitt, K.M.; Tenovuo, J.; Fleming, W.; Adamson, M

Determination of Inorganic Phosphate in Human Parotid Saliva by the Malachite Green

Method

Lagerlöf, F 324 
Saliva-Induced Aggregation of Streptococci. Solubilization of a Bacterial Surface Receptor (Short Communication)

Kashket, S.; Wang, Y.S.; Liberman, E.S 329

Animal Studies

Plasma Fluoride Levels and Enamel Fluorosis in the Rat

Angmar-Månsson, B.; Whitford, G.M 334

Contents V

Clinical Science

Dental Fluorosis and Localized Enamel Opacities in Fluoride and Nonfluoride Danish Com munities

Wenzel, A.; Thylstrup, A 340

A Scanning Electron Microscope Study, Showing that Plaque Does not Adhere to a Glass

Surface in the Mouth (Short Communication)

Winter, P.J.; Ridge, CM 349

No. 5 Basic Sciences

Fissure Sealants and Dental Enamel. A Histological Study of Microleakage in vitro

Hicks, M.J.; Silverstone, L.M353

Acid Hydrolysis of Aqueous Sodium Monofluorophosphate Solutions

Duff, E.J.; Stuart, J.L 361

Scanning Electron-Microscopic Observations on the in vitro Colonization of Human Den tine by Capnocytophaga gingivaíis

Adriaens, P.A.; Claeys, G.W.; De Boever, J.A 367

Production of Acids in Rat Dental Plaque with or without Streptococcus mutans

Hoeven, J.S. van der; Franken, H.C.M 375

Animal Studies

Effects of Different Eating Patterns on Dental Caries in the Rat

Edgar, W.M.; Bowen, W.H.; Amsbaugh, S.; Monell-Torrens, E.; Bundle, J384

Clinical Science

Evaluation of Cariostatic Disciplines for Postradiation Caries

Hutton, J.; Koulourides, T.; Borden, L 390

Feasibility of Radiographical Diagnosis in 8-Year-Old Schoolchildren with Low Caries

Activity

Ruiken, H.M.H.M.; Truin, G.J.; König, K.G 398

Relationship between Caries and Fluoride Uptake by Enamel from Two Fluoride Varnishes in a Community with Fluoridated Water

Seppä, L.; Hausen, H.; Luoma, H 404

Caries Prevalence in Danish Children Living in Areas with Low and Optimal Levels of

Natural Water Fluoride

Thylstrup, A.; Bille, J.; Bruun, C 413

No. 6 Editorial 421

Basic Sciences

Isolation and Partial Characterization of a Substance from Carrots, Daucus carota, with

Ability to Agglutinate Cells of Streptococcus mutans

Ramstorp, M.; Carlsson, P.; Bratthall, D.; Mattiasson, B 423

Fluoride Concentration in Human Fetal Enamel

Deutsch, D.; Gedalia, 1428 
VI

Contents

Progress of Artificial Carious Lesions in Enamel

Christoffersen, J.; Arends, J 433

Minimum Inhibitory Concentration of Surfactants for Plaque Antiadherents (Short Com

munication)

Lim, J.K.; Smith, S.; McGlothlin, J.; Gerencser, V.F440

Animal Studies

Influence of the Replacement of Dietary Sucrose by Maltose in Solid and in Solution on Rat

Caries

Skinner, A.; Connolly, P.; Naylor, M.N 443

Caries Prevention by Two Fluoride Varnishes in Osborne-Mendel Rats

Seppä, L.; Koskinen, M.; Luoma, H 453

Clinical Science

Effect of Plaque Mineralization on Experimental Dental Caries

Pearce, E.I.F 460

Effects of Sodium Phytate and Benzethonium Chloride Rinses on Plaque Formation in

Humans

Gaffar, A.; Rustogi, K.N. ' 472

Announcements

30th Annual ORCA Congress 1983

475

ORCA-Rolex Price 476

Honorary Membership 476

Acknowledgements $\quad 477$

Author Index 479

Subject Index 481

S. Karger · Medical and Scientific Publishers $\square$ Basel · München $\square$ Paris · London · New York ·

Tokyo $\cdot$ Sydney

Drug Dosage

The authors and the publisher have exerted every effort to ensure that drug selection and dosage set forth in this text are in accord with current recommendations and practice at the time of publication. However, in view of ongoing research, changes in government regulations, and the constant flow of information relating to drug therapy and drug reactions, the reader is urged to check the package insert for each drug for any change in indications and dosage and for added warnings and precautions. This is particularly important when the recommended agent is a new and/or infrequently employed drug.

All rights reserved.

No part of this publication may be translated into other languages, reproduced or utilized in any form or by any means, electronic or mechanical, including photocopying, recording, microcopying, or by any information storage and retrieval system, without permission in writing from the publisher.

S. Karger AG, P.O. Box, CH-4009 Basel (Switzerland) Printed in Switzerland by Buchdruckerei Basler-Zeitung, Basel 